\title{
A Reflection on Teaching Practice: A Masters Level 9 Microteaching Application
}

\section{Wright, Angela}

Department of OPD, School of Business, Ireland.

\begin{abstract}
I hear, and I forget. I see, and I remember. I do, and I understand (Asian Proverb).

The context of this research is the examinination of teaching practice through the lens of 'microteaching', thus affording the opportunity to reflect on and evaluate one's personal delivery with the view to instigating better actions for practice in the future. This study specifically contributes to a novel critical enhancement of level 9 teaching delivery where the cohort are adult learners. The focus of this evaluation on current practices is to establish where improvements could be made to teaching delivery through the direct scrutiny of peers. Reflection on the feedback and on the sessions was reviewed and recommendations were embraced and operationalised.

The empirical data was gathered through three peer review microteaching sessions that were recorded and where feedback was given after each session. The microteaching was repeated once a month over a 3-month interval process. Feedback from the sessions was analysed and recommendations for practice were developed. These recommendations will be considered, and relevant resultant changes will be made to improve future practice at level 9. It is envisaged that the findings of this research will better inform the author, the academic plan, and the faculty for future teaching practice.
\end{abstract}

Keywords: teaching practice, microteaching. 


\section{Introduction: Best Practices of T\&L in Higher Education}

At this juncture in the 21 st century, higher education (HE) is abuzz with conversations and activities regarding teaching \& learning (T\&L). Institutions are measuring $T \& L$ and considering best practices that may facilitate this. Altering one's own teaching practice is even more challenging, and less prevalent than measuring T\&L in general (Lewis, 2010). Improving $T \& \mathrm{~L}$ in higher education became an important international endeavour in the 1960s and 1970s, corresponding to an influx of students coming from a broader range of backgrounds, and with diverse expectations (Sorcinelli, et al., 2006:2). Academics now face even more challenges than before in higher education, with the engagement of students posing difficulties. Student and lecturer expectations can often be mismatched, posing much anxiety for both learner and those charged with delivery. Issues such as assessments and accountability, new technologies, diverse students, institutions striving to achieve 'the next level' etc., all impact on the pressures on both T\&L. Today, students are not afraid to voice their opinion or protest on delivery of course content or even resort to litigation. Opinionated student behaviour has challenged post-secondary institutions to modify traditional ways of teaching. No longer is a thorough knowledge of the subject matter enough to teach effectively (Lewis, 2010). In Ireland, an emphasis on increased strategic focus exists within institutions on the quality of T\&L (hea.ie). This has been supported by institution-level investments and through collaborative work undertaken in T\&L networks 1.

\subsection{Research Context: The Need to Engage Students and Facilitate Learning}

For many faculty members who are accustomed to lecturing 2 while students listen, learnercentred teaching may require new and unfamiliar teaching skills, and raise fears about lack of coverage of content or less control over assessments. Learner-centred teaching allows students to do more of the learning tasks, and learn more from and with each other (Weimer, 2002). Students learn differently in different situations, and surface and deep learning, for example, vary according to the academic task (Ramsden, 1992). Meaning is never the same from one person to the next, and a surface approach to learning leads down a desolate road (Entwistle, 2009; Ramsden, 1992). A deep approach to learning on the other hand is what all lecturers want their students to experience (Ramsden, 1992). Teachers who believe their job is to cover their course systematically by transmitting information to students are more likely to encourage surface learning approaches, where

\footnotetext{
${ }^{1}$ Irish Learning Technology Association (ILTA), Educational Developers in Ireland Network (EDIN), All-Ireland Society for Irish Higher Education (AISHE). Since 2000, a total of $€ 33.5 \mathrm{~m}$ has been invested in T\&L in Ireland in a period that has seen a transformation in the resourcing of T\&L, with greater availability and uptake of professional development (hea.ie).

${ }^{2}$ Teacher focused (concerned with subject matter), student focused (encouraging students to develop their own ways of understanding, (Entwistle, 2009).
} 
retention is temporary, generalisation of knowledge poor and learning how to learn is minimal. On the other hand, teachers who encourage student involvement in the learning process, for example by using Problem Based Learning (PBL), and focus on the quality of learning outcomes are more likely to encourage cognitively deeper and richer learning (cte.cornell.edu; Ingleton et al., 2000; Newble \& Cannon, 1995).

\section{Methodology}

This researcher has lectured and supervised on a Masters of Business programme since 2006. The student cohort consists of adult learners who come from diverse situations and positions. For this programme, deep learning (delivered through PBL) is paramount as is student-centred learning. Over the past number of years, research has been undertaken on this programme to ensure consistency in assessment, analysis of student feedback, outside industry based and programmatic reviews etc., but never on the in-class lecture delivery itself. The researcher therefore believed that the time had come after 12 years to examine one's own delivery and teaching practices in the classroom context through peer review microteaching analysis. Microteaching was developed at Stanford University in 1961 by Dwight W Allen as one part of an experimental teacher education programme supported by the Kettering and Ford Foundations (Allen, et al., 1968; Spelman, Brooks, 1972). This Stanford technique involved the steps of "plan, teach, observe, re-plan, re-teach and reobserve" (Remesh, 2013). Microteaching involves a small group of peer instructors teaching short lessons in front of each other to gain feedback (Donnelly \& Fitzmaurice, 2011). The lessons are recorded for later viewing and discussion. When the concept was first introduced peers were fearful of it as it was new for most and perceived as a stress to teach in front of one's peers. For the empirical element of this study, microteaching sessions took place over a three-month period - one session per month for 20 minutes (my regular lectures are 3 hours) on a topic familiar and comfortable for the researcher. The lecture took place in front of two colleagues from the T\&L Unit and the session was recorded for review later. Feedback sheets were filled in by the two peer reviewers and all data was shared and discussed with the lecturer afterwards. After the first session, the researcher reviewed and improved on practice and repeated the process over the following two months. After the last session, the researcher reflected on their own personal practice to improve same. The whole process was then reviewed and documented.

\section{Findings \& Discussion: A Reflection on Microteaching Sessions}

Microteaching can be a revealing and disturbing experience (Donnelly \& Fitzmaurice, 2011), but many find it beneficial. The sessions forced this researcher to stop for the first 
time, and take stock of my own teaching practices. I had to come out of my 'comfort zone'. I knew from the beginning that this would be stressful (Donnelly \& Fitzmaurice, 2011), but I persisted in the interest of improving practice. Certainly, presenting before one's peers is stressful. Reviewing the video of the session was instructive and enabled reflection and self-assessment.

Table 1. Self-Assessment findings from the First Session

\begin{tabular}{|l|l|}
\hline OBSERVATION & COMMENT \\
\hline $\begin{array}{l}\text { 1. I felt rushed. I didn't appear so in the video. } \\
\text { I knew that timing would be an issue for me, } \\
\text { as I have developed the habit in my own } \\
\text { teaching of revisiting an unfinished topic in } \\
\text { the next lecture }\end{array}$ & $\begin{array}{l}\text { 1. You may appear better to your } \\
\text { audience than you are feeling in } \\
\text { the session }\end{array}$ \\
\hline $\begin{array}{l}\text { 2. Watch timing! I omitted outlining what I } \\
\text { would cover in the session at the beginning }\end{array}$ & $\begin{array}{l}\text { 2. I will need to clarify this } \\
\text { (Entwistle, 2009) }\end{array}$ \\
\hline $\begin{array}{l}\text { 3. Always outline the content of the session in } \\
\text { advance, allowing time for a summary at the } \\
\text { end }\end{array}$ & $\begin{array}{l}\text { 3. Due to timing, I did not allow } \\
\text { time for questioning to check for } \\
\text { clarity of the session }\end{array}$ \\
\hline $\begin{array}{l}\text { 4. Check for understanding through } \\
\text { questioning }\end{array}$ & 4. Develop a process for this \\
\hline
\end{tabular}

\subsection{Self-Assessment from the Second Session}

In line with the (MIT, n.d), I was able to hone my skills and focus more clearly for the second session after a thorough reflection on the first experience. Analysis of the first session provided a great basis to improve the second session. I felt much better equipped the second time. Timing was much tighter, I included an interactive session in the form of projective techniques for the audience, I had sufficient time for a Q\&A session and I checked for clarity (Aithal, 2011; Entwistle, 2009). On the second occasion, I was certainly more relaxed. The peer feedback sheets also reflected these improvements.

\subsection{Self-Assessment from the Third Session: Reflection}

At the third session, this researcher was much more relaxed and by now well familiar with the process and constructive feedback from peers. Previous suggestions and corrections were implemented in this session. The peer feedback was encouraging and I had taken on board previous suggestions. At this stage, thoughts of how beneficial this overall exercise was in terms of future teaching in Higher Education were maturing in one's mind. The 
benefits of microteaching overall and how such sessions can be essential and most beneficial for lecture preparation came to the fore (Aithal, 2011). The final step now for the researcher was to reflect on the process for further betterment, and future implementation and this was enabled using (Gibbs, 1988). The following provides some (due to the limitations of this paper) but not all the insights of the reflection process.

\subsection{The Experience: Personal Teaching Practice Reflection-Gibbs six stages [A-F]}

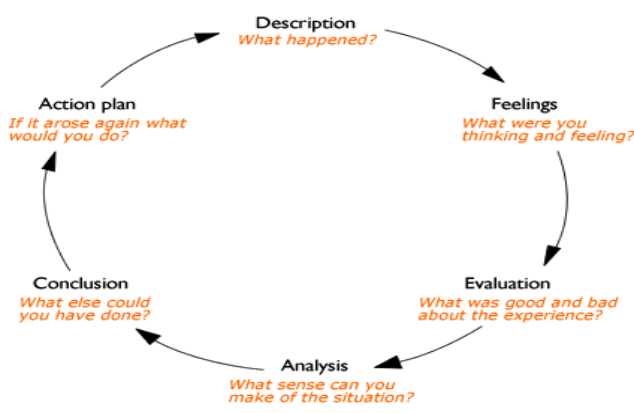

(Gibbs, 1988).

Diagram 1.

The reflective cycle

A: Description: What Happened?: The microteaching for the first time after 15 years of teaching forced me to examine and evaluate practice. In the past, I had been fooling myself into thinking that I had reviewed my practice, for example thinking - "That went well", "Students seem happy", "Results are good, the External examiner is happy". I now realise that this is a less than satisfactory approach and did not align with HE student education.

B: Feelings: Where I was in my own mind prior to the sessions and where I am now are at polar ends. I came to microteaching a confident lecturer (in my own head), and very much in my 'comfort zone', nothing was a problem, but undertaking the microteaching sessions, made me nervous initially; I now had to present something from my own subject area to my peers. I had to take time to prepare so that I would not appear foolish. Even so, on the first occasion, I still made mistakes in this session. In hindsight, the experience was positive for me. It challenged me to focus on my own lecturing skills. By the end of the process, I felt more like my own self, more confident and in control. Maybe my everyday lecturing had become second nature - a certain routine had set in, and I hadn't even realised this? The micro session was a complete new situation and experience for me and I found a new energy. I need to ensure that the 'everyday' does not become 'mundane' in my lecturing situation.

C: Evaluation: We evaluate to learn (Harvey, 1998). Microteaching forced me to evaluate and reflect on my own teaching and how my students learn. The evaluation in terms of 
peer feedback, was a 'first' for me, and forced me to deeply reflect and find ways to learn from my mistakes (Ramsden, 1992).

D: Analysis:

Table 2. How Microteaching Developed my Teaching

\begin{tabular}{|l|l|}
\hline OBSERVATION & COMMENT \\
\hline $\begin{array}{l}\text { 1. Forced me to seriously reflect on my } \\
\text { current teaching practices: critical self- } \\
\text { evaluation }\end{array}$ & $\begin{array}{l}\text { 1. Embrace more peer discussion and } \\
\text { review }\end{array}$ \\
\hline $\begin{array}{l}\text { 2. Add more clarity to the sessions } \\
\text { through questioning }\end{array}$ & $\begin{array}{l}\text { 2. Made me reflect on a new learning } \\
\text { experience and how daunting this } \\
\text { experience can be for students }\end{array}$ \\
\hline $\begin{array}{l}\text { 3. Encourage more group discussion in } \\
\text { class }\end{array}$ & $\begin{array}{l}\text { 3. Remind me of what it is like to be a } \\
\text { student again }\end{array}$ \\
\hline $\begin{array}{l}\text { 4. Change the habit of dragging topics } \\
\text { over weeks }\end{array}$ & $\begin{array}{l}\text { 4. Forced me to look more deeply at the } \\
\text { challenges that my own students face }\end{array}$ \\
\hline $\begin{array}{l}\text { Finally, I will embrace the set of seven features of lecturing outlined by Entwistle } \\
\text { (2009): Clarity, Level, Pace, Structure, Explanation, Enthusiasm, Empathy. }\end{array}$ \\
\hline
\end{tabular}

E: Conclusion: Recapturing the experience and 'mulling over it" is beneficial (Boud et al., (1985). It is paramount that we embrace aspects of our own practices that have been exposed through reflection from this research. The relationship between learner and teacher is complex, (Karmas, 2006), and I have found this to be especially true in the context of teaching the adult learner.

F: Action Plan: Microteaching afforded insight into myself, my students, assignments, assessments, and course content. We have a lot of thoughts, feelings and ideas (Moon, 2001), but we just need to reflect on them and draw meaningful concepts from them through reflection. My philosophy of teaching has now changed. In the future, I will engage in meaningful deep reflection, and would advocate that all departments and schools set up new processes for their staff to facilitate reflection, peer feedback and advice. Also, there is an overarching need to be even more reflective. We must be more proactive and not complacent (Moon, 2001). 


\section{Final Conclusion}

A love of learning is part of who I am, and this research afforded an opportunity to critique, learn again and embrace new techniques. An opportunity to gain valuable knowledge from one's peers, who provided very clever and interesting insights into their own methods and practices, is invaluable. Although a fearful prospect, the microteaching peer feedback proved most encouraging and supportive. The peer commentary was a very positive experience for me personally, and underpinned my confidence in terms of energy, movement, and gestures, which is reassuring (Aithil, 2011). Feedback offered me the opportunity to reflect (Donnelly \& Fitzmaurice; 2011; Moon, 2001), on my overall lecture preparation and ultimate delivery. We are always learning which is a great gift. If we are open to constructive criticism, enable ourselves to reflect on this and learn from it, we will never become bored with ourselves or boring in the eyes of our students. Hopefully, we will provide excitement, energy, and inspiration for our students to take with them into their future lives and careers. Our influence as teachers can have a profound effect on our students and shape their future careers.

\section{References}

Allen, D.W, Fortune, J.C., Cooper, J.M. (1968). The Stanford Summer Micro Teaching Clinic in Microteaching: a Description School of Education, Stanford University (Mimeo).

Aithal, S.C. (2011). “Micro Teaching Skills”, Dept. of Microbiology, Dnyanopasak College, Parbhani (MS) 431 410, available at http://www.scribd.com/doc/41047012/Micro-Teaching-Skills.

Boud, D., Keogh, R., Walker, D. (1985). "Promoting Reflection in Learning: A Model”. In D. Boud, R. Keogh, \& D. Walker (Eds), Reflection: Turning Experience into Learning. London: Kogan Page.

Cte.cornell.edu. "Problem-Based Learning; available at http://www.cte.cornell.edu/teaching-ideas/engaging-students/problem-basedlearning.html

Donnelly, R., Fitzmaurice, M. (2011). Towards Productive Reflective Practice in Microteaching, Learning, Teaching and Technology Centre, Dublin: Arrow, Dublin Institute of Technology.

Entwistle, N. (2009). Teaching for understanding at University, Deep approaches and distinctive ways of thinking, US: Palgrave Macmillan.

Gibbs, G. (1988). "The reflective Cycle", available at https://www.brookes.ac.uk/students/upgrade/study-skills/reflective-writing-gibbs/.

Harvey, J. (1998). Evaluation Cookbook, Edinburgh: The Learning Technology Dissemination Initiative. 
Hea.ie. "Review of the Allocation Model for Funding Higher Education Institutions Working Paper 10: Funding Teaching \& Learning Activity" available at http://hea.ie/assets/uploads/2017/06/HEA-RFAM-Working-Paper-10-Teaching-andLearning-072017.pdf.

Ingleton, C., Kiley, M., Cannon, R., Rogers, T. (2000). Leap into Student-centred Learning, Adelaide: The University of Adelaide AC.

Lewis K. (2010). "Pathways toward improving teaching and learning in higher education: International context and background". New Directions For Teaching \& Learning, 2010(122):13-23. Available from: Academic Search Complete, Ipswich, MA.

Karmas, C. (2006). "Active Learning in the Humanities Classroom, Everything, Nothing, Something, Anything", The international Journal of the Humanities, Active Learning in the Humanities Classroom, Vol.3. No.6.

MIT. Critical Moments Reflection Methodology, A Method for stepping back and draw lessons from the experience Center for Reflective Community Practice, available at http://www.kstoolkit.org/Critical+Moments.

Moon, J. (2001). "PDP Working Paper 4, Reflection in Higher Education Learning”, LTSN Generic Centre.

Newble, D. and Cannon, R. (1995). A handbook for teachers in universities and colleges: A guide to improving teaching methods. London: Kogan and Page.

Ramsden, P. (1992). Learning to Teach in Higher Education, NY:Routhledge Falmer.

Remesh, A. (2013). Microteaching, an efficient technique for learning effective teaching. Journal of Research in Medical Sciences: The Official Journal of Isfahan University of Medical Sciences, 18(2), 158-163.

Sorcinelli, M. D., A. E. Austin, P. L. Eddy, and A. L. Beach. (2006). Creating the future of faculty development: Learning from the past, understanding the present. San Francisco: Jossey-Bass, p.2.

Spelman, B.J., Brooks, St. John, C. (1972). Microteaching and teacher education: A Critical Reappraisal, Irish Journal of Education, vi, 2, pp.73-93.

Weimer, M. (2002). Learner-Centered Teaching. San Francisco, CA: Jossey-Bass Publishers. 